\title{
HISTOPATHOLOGY AND HISTOCHEMISTRY OF YERSIN TYPE TUBERCULOSIS IN RABBITS. ENZYMHISTOCHEMICAL STUDY OF DEVELOPMENT OF THE DISEASE AFTER INFECTION WITH MYCOBACTERIUM AVIUM
}

\author{
L. ČRNÝ \\ Department of Pathological Morphology and Parasitology, University of Veterinary Science,
} 61242 Brno

Received February 9, 1979

\begin{abstract}
Černý L.: Histopathology and Histochemistry of Yersin Type Tuberculosis in Rabbits. Enzymhistochemical Study of Development of the Disease after Infection with Mycobacterium avium. Acta Vet. Brno 49, 1980: 75-83.

Enzymhistochemical study of livers of rabbits infected experimentally with Mycobacterium avium revealed presence of changes in activity of some enzymes in the process of development of microscopic changes.

Activity of acid phosphatase was always present and especially high in macrophages and young epitheloid cells. At this stage of development of tuberculous lesions high activity of succinic, malic and isocitric dehydrogenases was present which showed high glycolytic activity of these cells. Development of pentoses and active pentose shunt in these cells revealed high activity of glucose-6-phosphate dehydrogenase. Activity of alkaline phosphatase was not connected to a considerable degree with cells of macrophage system. These cells revealed also activity of non-specific esterase, $\beta$-hydroxybutyrate and alcohol dehydrogenases.
\end{abstract}

Tuberculosis, Mycobacterium avium, Yersin type, enzymhistochemistry, hydrolases, dehydrogenases.

Tuberculous tissue and especially the cells of macrophage system reveal presence of activity of various enzymes. Their presence confirmed various authors. Activity of alkaline phosphatase is present mainly in cells of lymphocyte type and neutrophil leucocytes. These findings described Hori et al. (1953a, b), Merkal et al. (1968), Wertheimer (1968), Rajchlin (1971), Arabijskij (1975) etc. Some of the authors found limited activity of this enzyme in cytoplasm of few macrophages (Grusovin et al. 1976; Meier et al. 1977; Erochin 1978). During granuloma formation activity of alkaline phosphatase increased but in macrophages it was very limited, if any. Activity of acid phosphatase is according to the theory of De Duve 1963, 1966, 1970) connected with lysosomes. The question of presence of activity of lysosomal enzymes was studied by various authors e. g. Kurilov (1970), Mitin (1970), Armstrong and Hart (1971), Rajchlin (1971), Stossel et al. (1977), Davies (1976), Papadimitrious and Wyche (1976) etc. It was generally accepted that the activity of lysosome enzymes was one of proofs of cellular activity of macrophages. Activity of other hydrolase - non specific esterase was in the cells of macrophages system estimated always very high (Leder 1966; Merkal et al. 1968; Žuravleva 1970; Földes 1976; Meier et al. 1977).

In the course of development of various granulomas also presence of activity of various oxidoreductases was studied. Activity of succinic dehydrogenase described Sorokin et al. (1966), Hodel et al. (1966), Wertheimer (1968), Arabijskij (1975), Erochin (1978) etc. Similarly, in various cells of macrophage system activity of isocitric dehydrogenase was described (Allison et al. 1962; Hodel et al. 1966; Merkal et al. 1968; Žuravleva 1970; erc.). Activity of malic dehydrogenase was studied by Žuravleva (1970), Stuart et al. (1971), Žuravleva described 
also the presence of alcohol and $\alpha$-glycerophosphate dehydrogenase. Activity of glucose-6-phosphate dehydrogenase was also present in cells of macrophage system (Allison et al. 1962; Wertheimer 1968; Arabijskij 1975; Papadimitriou and Wyche 1976).

In development of various granulomas the cells of macrophage system revealed presence of whole series of enzymes. This work was concerned with activity of some enzymes during development of tuberculous lesions in rabbits after infection with Mycobacterium avium.

\section{Materials and Methods}

In the study 35 rabbits weighing about $1200 \mathrm{~g}$ were used. Thirty of these animals were infected intravenously with suspension of virulent strain of Mycobacterium avium using dosis of $0.01 \mathrm{mg}$ per $1 \mathrm{~kg}$. Remaining 5 rabbits were used as controls. Experimental animals were sacrificed 6 days, 10 days, 14 days, 18 days and 21 days after infection. Each experimental group consisted of 6 animals. For enzymhistochemical studies liver samples were taken. The tissues were chilled using liquid propan-butan at $-70^{\circ} \mathrm{C}$ or liquid nitrogen. Tissue samples were cut in cryostat and the sections were treated to reveal the presence of following enzymes: alkaline phosphatase A1P), acid phosphatase (AP), non-specific esterase (NE), succinic dehydrogenase (SDH), $\alpha$-glycerophosphate dehydrogenase (GPDH), malic dehydrogenase (MDH), isocitric dehydrogenase (ISCDH), $\beta$-hydroxybutyrate dehydrogenase (HBDH), alcohol dehydrogenase (A1DH), glucose6-phosphate dehydrogenase (G6PDH). Always also control sections were prepared.

\section{Results}

Activity of AlP was in all stages of development of the process comparatively low. It was connected mainly with lymphocytes scattered in granulation tissue eventually with few neutrophils. Neither macrophages nor epitheloid cells did reveal any visible positive reaction. At the time of necrobiosis of cells of macrophage

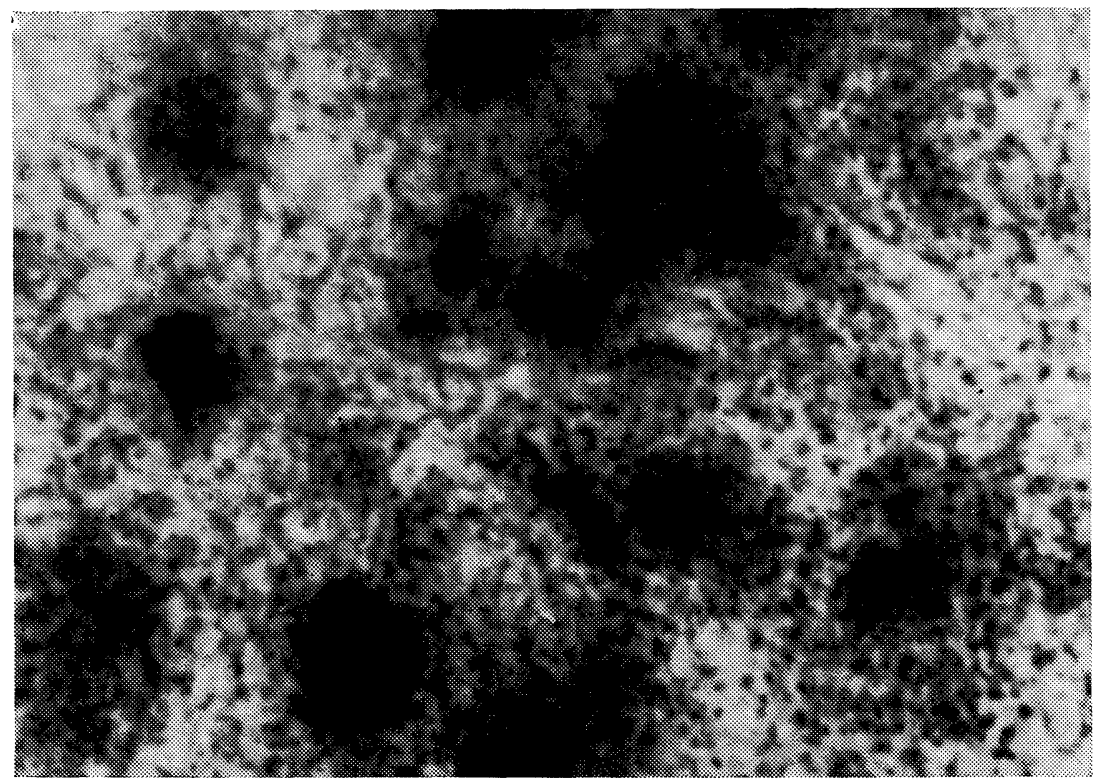

Fig. 1.

Acid phosphatase 18 days after infection. Strong activity in some macrophages and epitheloid cells. Naphtol ASD-phosphate - Fast Blue BB, $1600 \times$. 


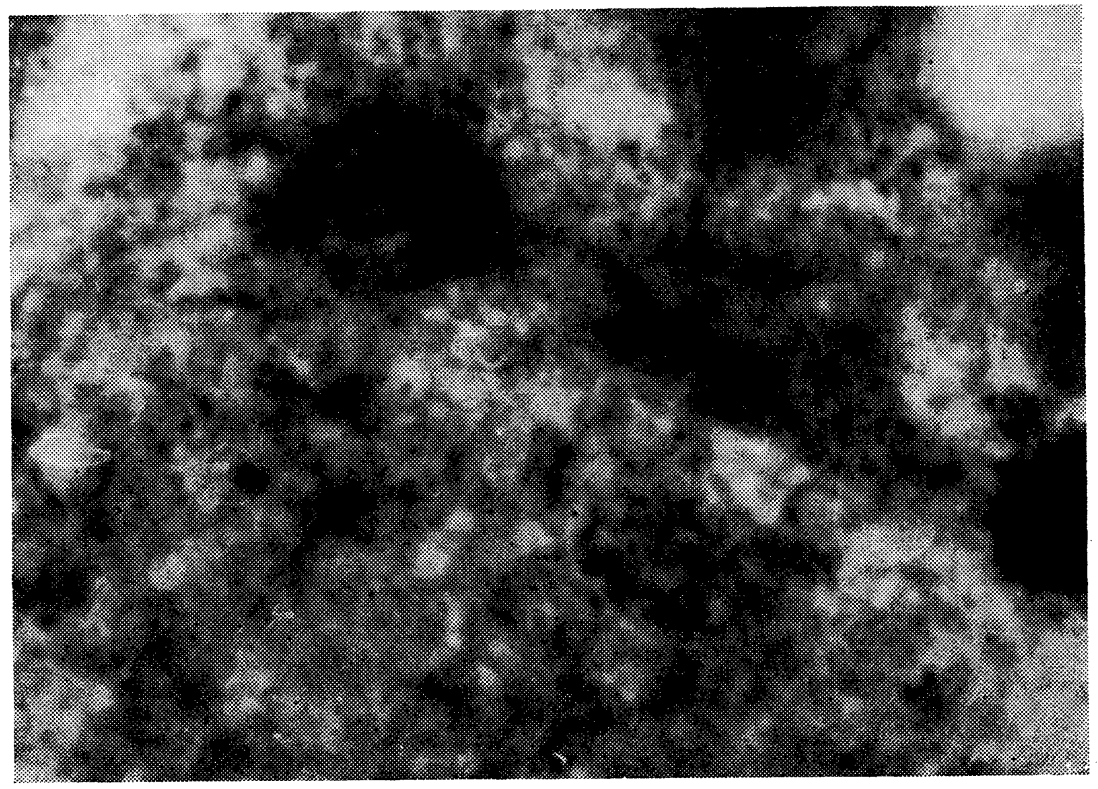

Fig. 2.

SDH, 14 days after infection. Positive reaction with mitochondrial localization in young epitheloid cells. NBT, $1.600 \times$.

system low activity of the enzyme was seen but in necrotic areas no positive reaction developed.

Acid phosphatase, a lysosomal enzyme, was active in the cells of macrophage system. The highest activity with lysosomal localization was in macrophages and developing epitheloid cells and in young giant cells. In older cells in the center of foci its lysosomal localization disappeared and the activity was diffuse in cytoplasm of these cells.

Activity of non-specific esterase was present in all cells of tuberculous granulomas and had diffuse character while in necrotic tissue the formazan was present in form of granules of various size and was intensively stained.

Succinic dehydrogenase activity showed varied intensity during development of the process. Kupffer's cells revealed comparatively low activity, in macrophages and young epitheloid cells its activity increased and later decreased up to complete loss in necrotic tissue. Similar finding was seen with sections revealing activity of malic dehydrogenase and NAD-isocitric dehydrogenase.

All cells of macrophages system revealed high activity of GPDH. This activity was present in Kupffer's cells, macrophages, epitheloid cells as well as giant cells and irregular activity was present in necrotic areas.

$\mathrm{HBDH}$ and AlDH were active nearly in all types of the cells of macrophage system. Their activity was less prominent than in other dehydrogenases and from these two the activity of $\mathrm{AlDH}$ was higher then $\mathrm{HBDH}$.

Some changes in activity were seen during development of cells of granulomas in G6PDH. The highest activity of this enzyme was present in epitheloid cells, especially in young epitheloid cells. 


\section{Enzyme activity of various cells of granulomas}

\begin{tabular}{|c|c|c|c|c|c|c|c|}
\hline Enzyme & Kupffer's cell & macrophage & $\begin{array}{l}\text { epitheloid } \\
\text { cell young }\end{array}$ & $\begin{array}{l}\text { epitheloid } \\
\text { cell old }\end{array}$ & $\begin{array}{c}\text { giant } \\
\text { cell }\end{array}$ & $\begin{array}{c}\text { necro- } \\
\text { biosis }\end{array}$ & $\begin{array}{c}\text { necro- } \\
\text { sis }\end{array}$ \\
\hline $\begin{array}{l}\text { A1P } \\
\text { AP } \\
\text { NE } \\
\text { SDH } \\
\text { MDH } \\
\text { ISCDH } \\
\text { A1DH } \\
\text { HBDH } \\
\text { GPDH } \\
\text { G6PDH }\end{array}$ & $\begin{array}{c}- \\
++ \\
++ \\
+ \\
+ \\
+ \\
++ \\
++ \\
+++ \\
++\end{array}$ & $\begin{array}{c}- \\
?+++ \\
++ \\
?++ \\
++ \\
++ \\
++ \\
++ \\
?+++ \\
+++\end{array}$ & $\begin{array}{c}- \\
+++ \\
++ \\
+++ \\
+++ \\
+++ \\
++ \\
++ \\
+++ \\
+++\end{array}$ & $\begin{array}{c}- \\
++ \\
++ \\
++ \\
++ \\
++ \\
++ \\
++ \\
+++ \\
++\end{array}$ & $\begin{array}{c}- \\
++ \\
++ \\
++ \\
+ \\
+ \\
++ \\
++ \\
+++ \\
++\end{array}$ & $\begin{array}{c}+ \\
+ \\
++ \\
+(-) \\
+(-) \\
+(-) \\
++ \\
++ \\
++ \\
+\end{array}$ & $\begin{array}{l}\overline{+} \\
+ \\
+ \\
- \\
- \\
- \\
++ \\
++ \\
++ \\
-\end{array}$ \\
\hline
\end{tabular}

$\begin{array}{ll}- & \text { negative } \\ + & \text { low activity } \\ ++ & \text { active } \\ +++ & \text { high activity } \\ +(-) & \text { not in all cells }\end{array}$

\section{Discussion}

Choice for intervals for experimental animals to be sacrificed was made according to the results of previous experiments. It was clear that in the development of morphological changes the interval of 6 days was convenient because specific changes had developed but there was no clear formation of epitheloid cells. Ten days after infection epitheloid cells were present and the process in liver developed very clearly after the $12^{\text {th }}$ day post infection. Therefore the process in liver was after 14 days in its full development. In further intervals the morphological changes in liver developed to a great extent.

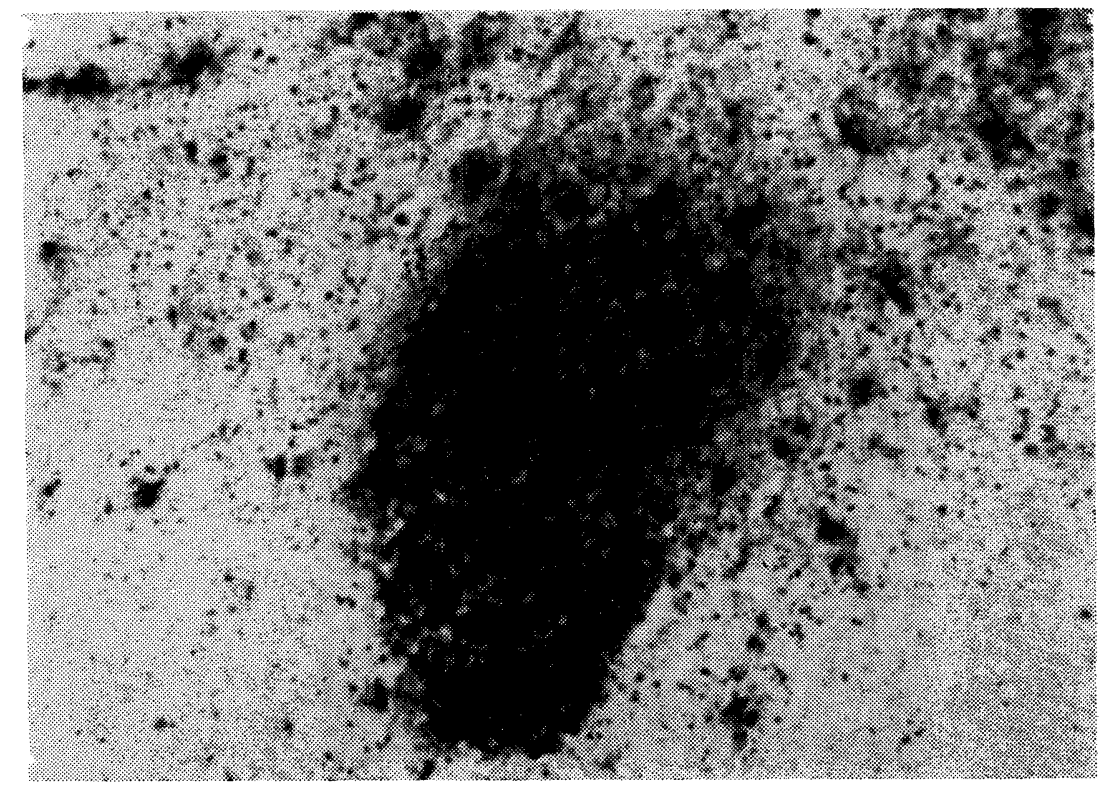

Fig. 3.

GPDH, strong activity in whole nodule and scattered Kupffers cells. NBT, $400 \times$. 
Literature data indicate that granuloma formation was followed very intensively. The findings were not always uniform e. g. the findings of activity of alkaline phosphatase concluded that activity of this enzyme was always present in granulomas but not in the cells of macrophage system (Hodel et al. 1966; Wertheimer 1968; Alley and Mankletow 1971; Rajchlin 1971; Arabijskij 1975 etc), while Grusovin et al. (1976), Meier et al. (1977), Erochin (1978) found activity of this enzyme also in macrophages although not in all of them. In this study activity of A1P in these cells was not detected. It was therefore generally concluded that acitivity of A1P was present in granulomas but the cells of macrophage system revealed only limited, if any, activity. It seemed that in the time of necrotization of cells of tuberculous tissue liberation of the enzyme ensued and its activity was visible.

Findings of acid phosphatase activity revealed that this enzyme was present in the cells of macrophage system at all stages. Especially high activity was in macrophages and epitheloid cells, $i$. e. those which were very active in phagocytosis of mycobacteria. Comparing to previous work, high activity of this enzyme corresponded to high content of RNA and diminished with loss of RNA and increasing amount of PAS-positive material in cytoplasm of these cells. From results of this study and from other studies (Stossel et al. 1972; Arabijskij 1975; Papadimitriou and Wee 1976; Turk et al. 1977 etc.) it is clear that these cells possess high phagocytic activity and ability to destroy mycobacteria. It is also clear that these cells possess a highly developed lysosomic apparatus which is very important for destruction of phagocyted material. It was also proved that during necrotisation of cells activity of AP lost its lysosomic localization and

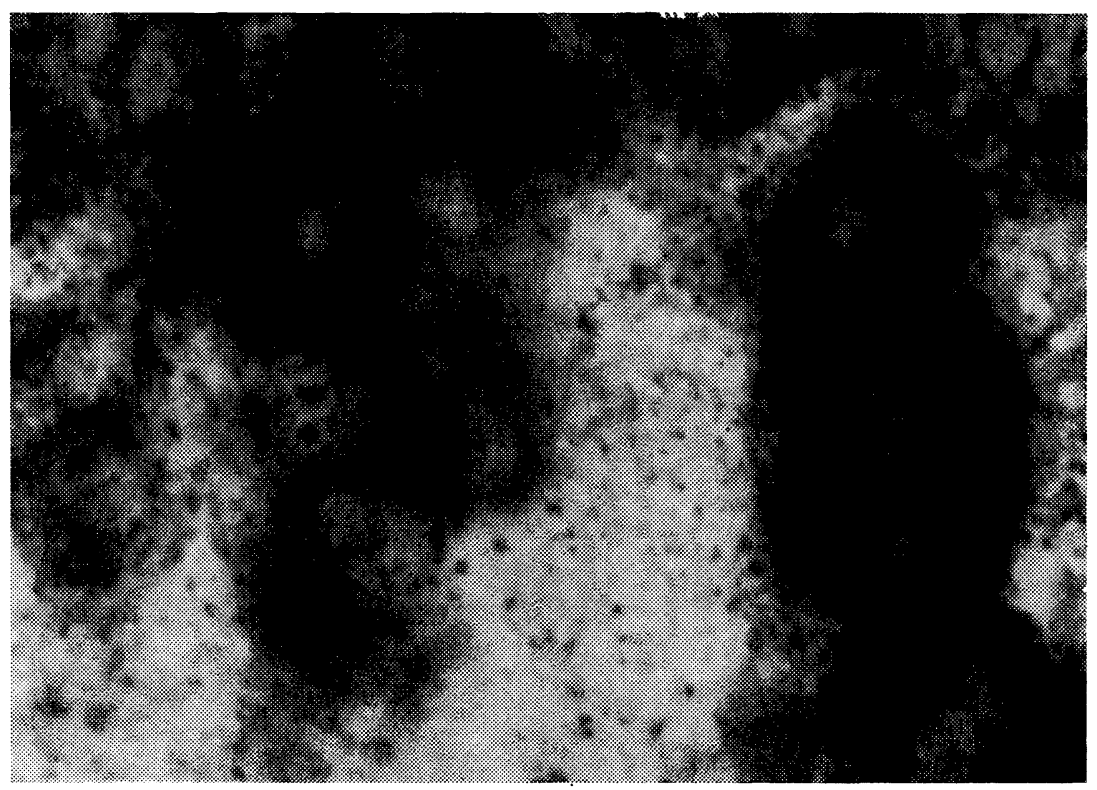

Fig. 4.

$\mathrm{HBDH}$, Margin of the lesion fast without reaction, high activity in liver cells. NBT, $1600 \times$. 


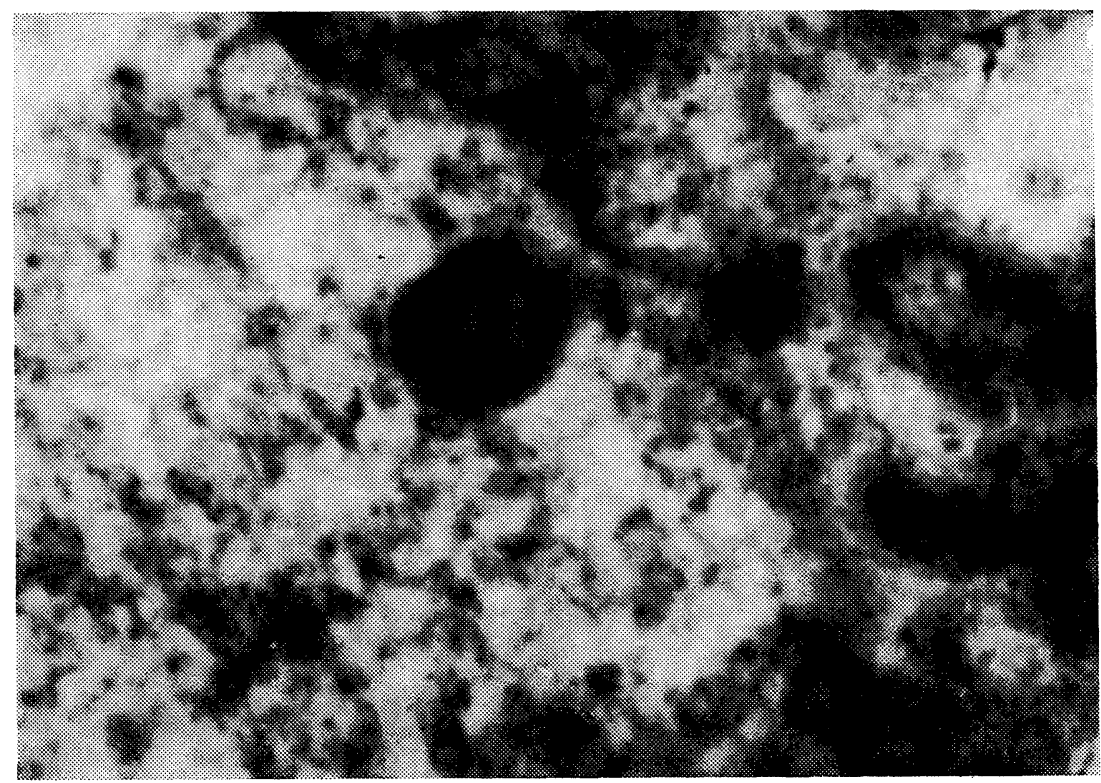

Fig. 5.

NE, 14 days after infection. The activity of liver cells higher. Naphtol AS-MX-acetate - Fast blue $\mathrm{B}, 1600 \times$.

following apparent destruction of lysosomes, the enzyme entered the cytoplasm where it could act proteolytically (Vturin and Orlov 1971; Rajchlin 1972).

Non-specific esterase activity was present in all cells of macrophage system although in the development of the process it did not change considerably. This finding corresponded to the statements of other authors e. g. Mestwerdt and Gusek 1968), Grusovin et al. (1976), Földes et al. (1976), Meier et al. (1977) etc. Activity of this enzyme was, according to the substrate employed (Naphtol AS-MX-acetate) lower in granulomas than in liver cells, intensity of staining depending upon the substrate. Meier et al. (1977) stated, that the cells of macrophage system revealed high activity of $\alpha$-naphtyl-acetate esterase. During necrotization of the cells enzyme apparently liberated from cells and its activity was present even in necrotic tissue.

Considerable changes with development of tuberculous lesions were seen in activity of SDH and to lesser extent MDH and ISCDH - all enzymes of Krebs cycle. Highest activity of SDH was in newly formed epitheloid cells and it seemed that expecially in this period the cells of tuberculous lesions had highest demand for energy to maintain their stability and function. Gradually, the activity of SDH and other enzymes of Krebs cycle decreased and this phenomena proved that even increased activity did not protect the cells from infection. It also showed that the process involved mitochondria and lead to decrease in glycolytic activity of the cells. That was evidently connected with increased amount of PAS-positive substances in cytoplasm of cells in ageing tuberculous lesions.

GPDH activity was always high in the cells: Kupffer's cell (monocyte), macrophage, epitheloid cell, multinucleated giant cell. This was to expect because activity 
of this enzyme is very high in all cells of macrophage system (Lojda et al. 1976). During necrosis this enzyme also liberated from the cells and its activity was present even in necrotic tissue in granular form. It evidently contributed to synthesis of triglycerides and phospholipids which were present in cytoplasm of cells during their necrotisation and in necrotic material.

Two other dehydrogenases did not reveal any considerable changes during development of the process, namely, A1DH and $\mathrm{HBDH}$, and activity was rather low. On the other hand, activity of G-6-PDH involved in synthesis of pentoses, which in their turn are needed for production of RNA, was high in developing young epitheloid cells. Those were the cells with highest content of RNA. Activity of this enzyme, the key enzyme of pentose shunt, was described also by Papadimitriou and Wyche (1976) and Arabijskij (1975).

According to results of this enzymhistochemical study of tuberculous lesions it was evident, that the cells of mononuclear macrophage system were very active and their activity decreased during degenerative changes of these cells. Study of activity of some enzymes, especially of acid phosphatase, succinic dehydrogenase, malic dehydrogenase, glucose-6-phosphate dehydrogenase could be used in estimating of phagocytic potencial of these cells.

This study has shown that tuberculous lesions in rabbits due to Mycobacterium avium were a convenient model for research in development of granulomas.

\section{Histopatologie a histochemie Yersinova typu tuberkulózy u králíků. Enzymhistochemické studium vývoje onemocnění po infekci Mycobacterium avium}

Enzymhistochemické studium jater králíků, infikovaných experimentálně $M y c o-$ bacterium avium prokázalo, že $\mathrm{v}$ průběhu onemocnění docházi ke změnám $\mathrm{v}$ aktivitě některých enzymů.

Vždy je silná aktivita kyselé fosfatázy a zvláště vysoká je u makrofágů a mladých epiteloidních buněk. $V$ tomto stadiu vývoje tuberkulózního procesu je také vysoká aktivita sukcinát dehydrogenázy, malát a izocitrát dehydrogenázy, která svědčí o vysoké glykolytické aktivitě těchto buněk. Tvorba pentóz a aktivní pentózový cyklus byl zjištěn $\mathrm{v}$ těchto buňkách $\mathrm{v}$ souvislosti s vysokou aktivitou glukózo-6-fosfát dehydrogenázy. Aktivita alkalické fosfatázy není ve větší míre vázána na buňky makrofágového systému. Tyto buňky vykazuji také aktivitu nespecifické esterázy, beta-hydroxybutyrát dehydrogenázy a alkohol dehydrogenázy.

Гистопатология и гистохимия типа Иерсена туберкулеза кроликов. Энзимгистохимическое исследование развития забовления после инфекции Mycobacterium avium

Энзимгистохимическое изучение печени кроликов, экспериментально пюфицированных Mуcobacterium avium выявило, что в ходе заболевания имеют место изменения активности некоторых энзимов.

Большой интенсивностью всегда отличается активность кислой фосфатазы, в особенности высокой является в случае макрофагов и молодых эпителиоидных клеток. На данной стадии развития процесса туберкулеза имеется также высокая активность сукцинат дегидрогеназы, малат и изоцитрат дегидрогеназы, свидетельствующая о высокой гликолитической активности данных клеток. Образование пентоз и активный пентозный цикл был в данных клет- 
ках выявлен в связи с высокой активностью глюкозо-6-фосфат дегидрогеназы. Активность щелочной фосфатазы не связана в большой степени с клетками макрофаговой системы. Настоящие клетки отличаются также активностью неспецифической әстеразы, бета-оксибутират дегидрогеназы и алкоголь дегидрогеназы.

\section{References}

ALLEY, M. R. - MANKLETOW, B. W.: Alveolar epithelisation in ovine pneumonia. J. Pathol. (Edinburgh), 103, 1971: 219-224.

ALLISON, M. G. - ZAPPASODI, P. - LURIE, M. B.: Metabolic studies in mononuclear cells from rabbits of various genetic resistance to tuberculosis. II. Studies on cells from BCG vaccinated animals. Am. Rev. resp. Dis., 85, 1962: 364-372.

ARABIJSKIJ, R. A.: Citochimija fagocitarnych kletok u senzibilizovannych životnych. Arch. Pat. (Moskva), 37, c. 9, 1975: 16-22.

ARMSTRONG, J. A. - HART, P. D'Arcy: Response of cultured macrophages to Mycobacterium tuberculosis with observations on fusion of lysosomes with phagosomes. J. exp. Med., 134, 1971: 713-740.

DAVIES, P.: Essential role of macrophage in chronic inflammatory processes. Schweiz. med. Wchschr., 106, 1976: 1351-1354.

De DUVE, CH.: The lysosome. Scient. American, 20, 1963: 644-72.

De DUVE, CH.: Die Rolle der Lysosomen in der Zellpathologie. Triangel, 9, 1970: 200-208.

De DUVE, CH. - WATTIAUX, R.: Functions of lysosomes. Ann. Rev. Physiol., 28, 1966: 435-492.

EROCHIN, V. V.: Morfofukcionalnoje sostojanie kletočnych elementov tuberkuleznoj granulomy. Arch. Pat. (Moskva), 40, č. 6, 1978: 37-45.

FÖLDES, I. In: RAJKA, E. - KOROSSY, S. (ed.): Immunological aspects of allergy and aller gic diseases., Vol. 8, p. 37-71, Akademia kiadó, Budapest! 1976.

GRUSOVIN, G. D. - BEARZI, I. - RIGOBELLO, P. - ZAVAGLI, G.: Osservazioni citochimice ed ultrastrutturale sul marcofago alveolare. Rev. Patol. Clin. e Sper., 16, 1976: 83-106.

HODEL, C. - MEYER-RUGE, W.: Die pathologische Riesenzelle im histotopochemischen Enzymbild. Verh. dtsch. Ges. Path., 1966: 399-402.

HORI, H. - HATTORI, S. - HAGIHARA, T.: Histochemical study on the histogenesis of tuberculous lesions in the lung. I. Nucleic acids, mucopolysaccharides, alkaline phosphatase in pulmonary lesions of tuberculous patients. Med. J. Osaka Univ., 4, 1953: 329-340.

HORI, M. - HATTORI, S. - HAGIHARA, T.: Histochemical study on the histogenesis of tuberculous lesions in the lung. II. Histogenesis of pulmonary tuberculosis in guinea pigs. Med. J. Osaka Univ., 4, 1953: $341-351$.

KURILOV, V. Ja.: Lizozomy v patologii lepry. Arch. Pat. (Moskva), 33, c. 4, 1970: 28-31.

LEDER, L. D.: Fermentcytochemische Untersuchungen zur Herkunft des Blutmonocyten. Klin. Wchschr., 44, 1966: 25-30.

LOJDA, Z. - GOSSRAU, R. - SCHIEBLER, T. H.: Enzym-histochemische Methoden. Springer Verlag, Berlin, Heidelberg, New York, 1976: 300 str.

MEIER, C. J. L. M. - van de PUTTE, L. B. A. - EULDERINK, F. - KLEINJAN, R. LAFEBER, G. - BOTS, G. Th, A. M.: Characteristics of mononuclear cell populations in chronically inflammed synovial merhbranes. J. Path. (Edinburgh), 121, 1977: 1-8.

MERKAL, R. S. - KLUGE, J. P. - MONLUX, W. S. - LARSEN, A. B. - KOPECKY, K. E. - QUINN, L. Y. - LEHMANN, R. P.: Experimental paratuberculosis in sheep after oral, intracheal or intravenous inoculation: Histochemical localization of hydrolase activities. Amer. J. vet. Res., 29, 1968: 985-994.

MERKAL, R. S. - MONLUX, W. S. - KLUGE, J. P. - LARSEN, A. B. - KOPECKY, K. E. - QUINN, L. Y. - LEHMANN, R. P.: Experimental paratuberculosis is sheep after oral, intratracheal, or intravenous inoculation: histochemical localization of dehydrogenase activities. Amer. J. vet. Res., 29, 1968: 971-982.

MESTWERDT, W. - GUSEK, W.: Histomorphologie und Cytochemie von experimentellen Beryliumgranulomen in der Meerschweinchenhaut. Hautartzt, 19, 1968: 56-61.

MITIN, K. S.: Elektronnaja gistochimia. Někotorye aspekty sorvemennoj funkcionalnoj morfologii. Arch. Pat. (Moskva), 32, č. 1, 1970: 9-21.

PAPADIMITRIOU, J. M. - WEE, S. H.: Selective release of lysosomal enzymes from cell populations containing multinucleated giant cells. J. Path. (Edinburgh), 120, 1976: 193-200.

PAPADIMITRIOU, J. M. - WYCHE, P. A.: A biochemical profile of glass-adherent cell populations containing multinucleated giant cells. J. Path. (Edinburgh), 119, 1976: 239-254. 
RAJCHLIN, N. T.: Lizozomy v norme i v patologii. Arch. Pat. (Moskva), 33, č. 4, 1971: 73-82.

STOSSEL, T. P. - MASON, R. J. - POLLARD, T. D. - VAUGHAN, M.: Isolation and properties of phagocytic vesicles. II. Alveolar macrophages. J. clin. Invest., 51, 1972: 604-614. STUART, A. E. - DAVIDSON, A. E.: The human reticular cell: morphology and cytochemistry. J. Pathol. (Edinburgh), 103, 1971: 41-47.

VTTURIN, B. V. - ORLOV, G. N.: Někotoryje voprosy funkcionalinoj morfologii lizozom. Arch. Pat. (Moskva), 33, č. 4, 1970: 8-17.

WERTHEIMER, F. W.: Enzyme histochemistry of giant-cell reparative granulomas. Oral Surg., 23, 1967: 464-469.

ŽURAVLEVA, G. F.: Gistofermentologičeskaja charakteristika koži bolnych lepromatoznoj prokazoj. Arch. Pat. (Moskva), 33, č. 4, 1970: 32-36. 